Article

\title{
Effects of pretreatment temperature on bimetallic Ir-Re catalysts for glycerol hydrogenolysis
}

\author{
Chenghao Deng, Li Leng, Jinghong Zhou*, Xinggui Zhou, Weikang Yuan \\ State Key Laboratory of Chemical Engineering, East China University of Science and Technology, Shanghai 200237, China
}

\section{A R T I C L E I N F O}

Article history:

Received 11 March 2015

Accepted 16 May 2015

Published 20 October 2015

\section{Keywords:}

Glycerol hydrogenolysis

Iridium-Rhenium alloy

Bifunctional mechanism

Surface acidity

Reduction temperature

\begin{abstract}
A B S T R A C T
A series of bimetallic Ir-Re/KIT-6 catalysts was prepared by direct activation of impregnated samples at various reduction temperatures to study the effect of pretreatment temperature on catalyst structure and on catalytic performance for glycerol hydrogenolysis. All catalysts were characterized by $\mathrm{N}_{2}$ adsorption-desorption, transmission electron microscopy, CO chemisorption, in-situ CO adsorption diffuse reflectance infrared Fourier transform spectroscopy and temperature-programmed desorption of ammonia ( $\mathrm{NH}_{3}$-TPD). The results demonstrated that those catalysts reduced at 400 to $700{ }^{\circ} \mathrm{C}$ exhibited an Ir-Re alloy structure with similar particle sizes and Ir dispersions. Furthermore, $\mathrm{NH}_{3}$-TPD results indicated that all catalysts had similar acid strengths, though acid density varied with the reduction temperature. Increasing the pretreatment temperature from 400 to $600{ }^{\circ} \mathrm{C}$ monotonically increased the acid density of the catalysts and also improved the catalytic activity for glycerol hydrogenolysis. Reducing the Ir-Re alloy catalyst at $700{ }^{\circ} \mathrm{C}$ slightly decreased the activity due to the growth of the metal particles. Moreover, a linear relationship was identified between the acid density of a catalyst and its activity, verifying the vital roles of both Re and surface acidity with regard to optimizing the performance of Ir-Re alloy catalysts.
\end{abstract}

(C) 2015, Dalian Institute of Chemical Physics, Chinese Academy of Sciences. Published by Elsevier B.V. All rights reserved.

\section{Introduction}

The transformation of biomass and its derivatives to commodity chemicals is an attractive means of addressing the anticipated shortage of fossil fuel sources [1,2]. As a by-product in biodiesel processing, glycerol is regarded as a biomass derivative and thus a renewable chemical building block $[3,4]$. Tremendous efforts have been directed toward the conversion of glycerol to valuable chemicals through reduction processes such as dehydration [5-8] and hydrogenolysis [9-17], while hydrogenolysis to propanediols is one of the most promising approaches. As shown in Scheme 1, the hydrogenolysis of glycerol produces 1,3-propanediol (1,3-PD), 1,2-propanediol (1,2-PD), 1-propanol (1-PO) and 2-propanol (2-PO), of which
1,3-PD is the most valuable. Generally, efficient catalysts for the production of 1,3-PD from glycerol are composed of a highly reducible noble metal $(\mathrm{Pt}, \mathrm{Ir}$, or $\mathrm{Rh}$ ) together with a species containing an oxophilic metal such as Re or W [10-17], including $\mathrm{Ir}-\mathrm{ReO}_{x} / \mathrm{SiO}_{2}$, Pt-Re/C and Pt/ $\mathrm{WO}_{3} / \mathrm{AlOOH}$. Recently, our group proposed an Ir-Re alloy catalyst supported on KIT-6 (an ordered mesoporous silica with a cubic arrangement of interconnected pores) as a potential glycerol hydrogenolysis catalyst, and determined that this material exhibits the fastest yet 1,3-PD formation rate $\left(25.6 \mathrm{~mol} \cdot \mathrm{mol}_{\mathrm{Ir}}{ }^{-1} \cdot \mathrm{h}^{-1}\right)$ at $63.3 \%$ glycerol conversion [18].

The hydrogenolysis of glycerol is a structure-sensitive reaction [12,19]. The catalytic performance relies heavily on the structure of the bimetallic catalyst [12-13], which in turn is

\footnotetext{
* Corresponding author. Tel: +86-21-64252169; Fax: +86-21-64253528; Email: jhzhou@ecust.edu.cn This work was supported by the National Natural Science Foundation of China (21106047). 


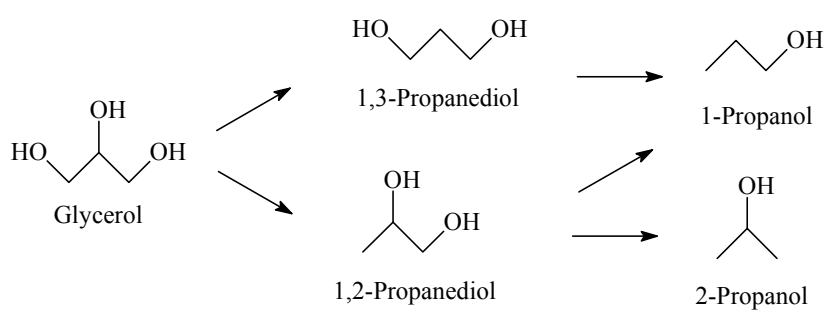

Scheme 1. Reaction pathways during glycerol hydrogenolysis.

related to the catalyst preparation parameters [13-14,20-24]. As an example, variations in both the reduction and calcination temperatures can change the bimetallic $\mathrm{Pt}-\mathrm{Cu}$ interaction and the extent of surface coverage by copper, thus affecting the catalytic performance of Pt-Cu catalysts during nitrate reduction [24]. Daniel and co-workers found that higher reduction temperatures result in improved atomic mixing of $\mathrm{Pt}$ and $\mathrm{Re}$ and better catalytic performance of a Pt-Re/C catalyst during the hydrogenolysis of glycerol [13]. Recently, we proposed that the bimetallic Ir-Re structure and thus its catalytic performance could be influenced by applying different thermal treatment procedures [18]. Producing the Ir-Re/KIT-6 catalyst without a calcination pretreatment renders the Re species fully reducible and thus the Re couples with Ir to form an Ir-Re alloy following reduction at $500{ }^{\circ} \mathrm{C}$. On the contrary, the combination of calcination and subsequent reduction results in the formation of an Ir-ReO ${ }_{x}$ structure $[10,17]$. In our previous work, we proposed a possible bifunctional mechanism for the Ir-Re alloy catalyst involving both metallic Ir and acidic (Ir-)Re-OH sites. The higher surface acidity of the Ir-Re alloy catalyst was seen as possibly being responsible for its higher activity. Although analogous bifunctional mechanisms have been proposed in the cases of bimetallic Ir-Re, Rh-Re and Pt-Re catalysts during C-O scission reactions based on studies involving density functional theory (DFT) simulations $[12,23,27,33]$, to the best of our knowledge, the role of the surface acidity of a bimetallic Ir-Re catalyst and the possible bifunctional mechanism have not yet been fully demonstrated based on experimental results.

In the present work, a series of bimetallic Ir-Re/KIT- 6 catalysts was prepared by a direct reduction method. The effects of the reduction temperature on the nature of the bimetallic Ir-Re catalysts and on their catalytic performance were studied as a means of examining the structure-activity relationship. This study therefore provides insights into the role of surface acidity during glycerol hydrogenolysis over bimetallic Ir-Re catalysts.

\section{Experimental}

\subsection{Catalyst preparation}

KIT-6 was synthesized using P123 (Aldrich, MW = 5800) as the structure-directing agent and TEOS (Shanghai Lingfeng Chemical Reagent Co., Ltd., 99.0\%) as the silica source, according to a previously published procedure [30]. In a typical preparation, $4.0 \mathrm{~g}$ P123 was dissolved in a mixture of $144 \mathrm{~g}$ distilled water and $7.9 \mathrm{~g} \mathrm{HCl}(35 \mathrm{wt} \%)$ and mixed at $35^{\circ} \mathrm{C}$ for $3 \mathrm{~h}$. After complete dissolution of the P123, $4.0 \mathrm{~g}$ n-BuOH was added and the mixture was stirred for $1 \mathrm{~h}$. Subsequently, $8.6 \mathrm{~g}$ TEOS was added dropwise to the solution. The mixture was then stirred at $35{ }^{\circ} \mathrm{C}$ for $24 \mathrm{~h}$ before hydrothermal treatment at $110{ }^{\circ} \mathrm{C}$ in a polypropylene bottle for a further $24 \mathrm{~h}$. The resulting precipitate was collected by filtration and then calcined at $550{ }^{\circ} \mathrm{C}$ in air for $5 \mathrm{~h}$.

Bimetallic Ir-Re catalysts supported on KIT-6 were prepared by a consecutive incipient wetness impregnation method using an aqueous solution of $\mathrm{H}_{2} \mathrm{IrCl}_{6}$ (Sigma-Aldrich, 99.9\%) and $\mathrm{NH}_{4} \mathrm{ReO}_{4}$ (Sigma-Aldrich, 99.0\%) [18]. In a typical procedure, Ir/KIT- 6 was first prepared by the incipient wetness impregnation of KIT- 6 with the required amount of an aqueous solution of $\mathrm{H}_{2} \mathrm{IrCl}_{6}$, aged overnight and then dried at $120{ }^{\circ} \mathrm{C}$ for $12 \mathrm{~h}$. The Ir-Re/KIT- 6 was then obtained by impregnating the dried Ir/KIT-6 with an aqueous solution of $\mathrm{NH}_{4} \mathrm{ReO}_{4}$. The impregnated samples were aged overnight and then dried at 120 ${ }^{\circ} \mathrm{C}$ for $12 \mathrm{~h}$. Subsequently, the samples were reduced at 400 , 500,600 or $700{ }^{\circ} \mathrm{C}$ in pure $\mathrm{H}_{2}(70 \mathrm{~mL} / \mathrm{min})$ for $3 \mathrm{~h}$, then passivated in $1 \% \mathrm{O}_{2} / \mathrm{Ar}$ for $20 \mathrm{~min}$ at room temperature. The exact loadings of Ir and Re were 4.1 and $3.8 \mathrm{wt} \%$, respectively, as determined by inductively coupled plasma atomic emission spectroscopy (ICP-AES) analysis.

\subsection{Glycerol hydrogenolysis}

Reactions were carried out in a 100-mL stainless steel autoclave (Parr Instruments) equipped with an electronic temperature controller and a magnetic stirrer. In a typical procedure, $20 \mathrm{~g}$ of an aqueous $20 \mathrm{wt} \%$ glycerol solution and $0.15 \mathrm{~g}$ catalyst were loaded into the autoclave. The reactor was purged three times with $2 \mathrm{MPa} \mathrm{H}_{2}$, then heated to $120^{\circ} \mathrm{C}$, pressurized to 8 $\mathrm{MPa}$ and stirred at $500 \mathrm{r} / \mathrm{min}$. The samples were analyzed using ultra performance liquid chromatography (UPLC, Waters 2414) together with a refractive index (RI) detector and a C18 AQ column. The carbon balance in all tests was found to be greater than $95 \%$. Conversion, selectivity and specific reaction rates were calculated as follows:

$$
\begin{gathered}
\text { Conversion }(\%)=\frac{(\text { mol of glycerol converted })}{(\text { mol of glycerol charged })} \times 100 \\
\text { Selectivity }(\%)= \\
\frac{(\text { mol of product }) \times(\text { number of carbon atoms in the product })}{(\text { Sum of carbon-based mol for all liquid products })}
\end{gathered}
$$

Specific rate $\left(\mathrm{mol} \cdot \mathrm{mol}_{\mathrm{Ir}}{ }^{-1} \cdot \mathrm{h}^{-1}\right)=\frac{(\mathrm{mol} \text { of glycerol converted })}{(\text { mol of Ir charged }) \times(\text { reaction time })}$

\subsection{Characterizations}

Metal loadings were determined by ICP-AES (Vanan 710). $\mathrm{N}_{2}$ adsorption-desorption was performed using a Micromeritics ASAP $2010 \mathrm{C}$ apparatus at $-196{ }^{\circ} \mathrm{C}$ after out-gassing the samples at $300{ }^{\circ} \mathrm{C}$ and $133.3 \mathrm{~Pa}$ for $6 \mathrm{~h}$. X-ray diffraction (XRD) was performed with a Rigaku D/Max 2550VB/PC diffractometer using $\mathrm{Cu} K_{\alpha}(\lambda=0.15406 \mathrm{~nm})$ radiation. Transmission electron 
microscope (TEM) characterization of the reduced Ir-Re/KIT-6 catalysts was conducted using a JEOL JEM 2100 with an accelerating voltage of $200 \mathrm{kV}$ and a point resolution of $0.18 \mathrm{~nm}$. Mean particle sizes and particle size distributions were determined by measuring more than 200 randomly selected metal particles.

Temperature-programmed reduction (TPR) data were acquired using a Micromeritics AutoChem 2920 together with a U-shaped quartz reactor equipped with a thermal conductivity detector, under $5 \% \mathrm{H}_{2} / \mathrm{Ar}(30 \mathrm{~mL} / \mathrm{min})$. The sample quantities ranged from 40 to $70 \mathrm{mg}$ and the temperature was increased from ambient to $800{ }^{\circ} \mathrm{C}$ at $10{ }^{\circ} \mathrm{C} / \mathrm{min}$. CO chemisorption was carried out at $45{ }^{\circ} \mathrm{C}$. Prior to each measurement, the sample was reduced in situ at $500^{\circ} \mathrm{C}$ for $1 \mathrm{~h}$ under $\mathrm{H}_{2} / \mathrm{Ar}(40 \mathrm{~mL} / \mathrm{min})$, then purged with $\mathrm{Ar}$ at $530{ }^{\circ} \mathrm{C}$ for $30 \mathrm{~min}(40 \mathrm{~mL} / \mathrm{min})$ and finally cooled to $45^{\circ} \mathrm{C}$. The number of surface Ir sites was taken as equal to the irreversible $\mathrm{CO}$ uptake based on the CO diffuse reflectance infrared Fourier transform (DRIFT) spectra.

DRIFT spectra were recorded on a Nicolet 6700 FTIR spectrophotometer in the diffuse reflectance mode, using an in situ cell equipped with a sample cup, heater and ZnSe windows. Pre-reduced or passivated samples were placed into the sample cup and reduced in situ at $350{ }^{\circ} \mathrm{C}$ under a $\mathrm{H}_{2}$ flow for $1 \mathrm{~h}$. Each sample was then cooled to room temperature, after which $2 \% \mathrm{CO} / \mathrm{Ar}$ was introduced until the $\mathrm{CO}$ coverage reached its saturation level. Spectra were collected at room temperature after purging with Ar.

Temperature-programmed desorption of ammonia ( $\mathrm{NH}_{3}$-TPD) was performed using a Micromeritics AutoChem 2920 to assess the acidic properties of the Ir-Re/KIT-6 catalysts. All samples were pre-reduced under a hydrogen flow at a corresponding temperature for $3 \mathrm{~h}$ and subsequently passivated under $1 \% \mathrm{O}_{2} / \mathrm{Ar}$ for $20 \mathrm{~min}(30 \mathrm{~mL} / \mathrm{min})$ at room temperature. The reduced Ir-Re/KIT-6 samples were used for $\mathrm{NH}_{3}$-TPD measurements, while the total amount of acid was also determined by measuring the $\mathrm{NH}_{3}$ uptake of the specimen. Prior to measurements, the sample was degassed in a $\mathrm{He}$ stream $(20 \mathrm{~mL} / \mathrm{min})$ at $500{ }^{\circ} \mathrm{C}$ for $1 \mathrm{~h}$ and then cooled to $100{ }^{\circ} \mathrm{C}$ in He. The sample was subsequently exposed to a mixed gas flow of $10 \% \mathrm{NH}_{3}$ and $90 \% \mathrm{He}(50 \mathrm{~mL} / \mathrm{min})$ to allow for sufficient adsorption of $\mathrm{NH}_{3}$ and then exposed to a He flow for 30 min. Finally, the temperature was raised to $500{ }^{\circ} \mathrm{C}$ at $5{ }^{\circ} \mathrm{C} / \mathrm{min}$ under a He flow $(50 \mathrm{~mL} / \mathrm{min})$. The acid amounts were estimated from the calibrated peak areas of the $\mathrm{NH}_{3}$-TPD profiles based on the relationship between the peak area and the amount of $\mathrm{NH}_{3}$ desorbed.

\section{Results and discussion}

\subsection{Catalyst characterization}

$\mathrm{N}_{2}$ adsorption-desorption was performed to investigate possible changes in the textural properties of the Ir-Re/KIT-6 catalysts upon applying different thermal treatments. The resulting data (Table 1 and Fig. 1) indicate that the introduction of metal species results in a decrease in both the surface area and the pore volume, most likely because of the localization of
Table 1

Physical-chemical properties of KIT-6, Ir/KIT-6 and Ir-Re/ KIT-6 samples.

\begin{tabular}{lcccccc}
\hline Sample & $\begin{array}{c}S_{\text {BET }^{\mathrm{a}}} \\
\left(\mathrm{m}^{2} / \mathrm{g}\right)\end{array}$ & $\begin{array}{c}V_{\mathrm{p}}^{\mathrm{b}} \\
\left(\mathrm{cm}^{3} / \mathrm{g}\right)\end{array}$ & $\begin{array}{c}d_{\mathrm{p}} \mathrm{c} \\
(\mathrm{nm})\end{array}$ & $\begin{array}{c}D^{\mathrm{d}} \\
(\%)\end{array}$ & $\begin{array}{c}\text { Total acid } \\
\text { amount } \\
(\mu \mathrm{mol} / \mathrm{g})\end{array}$ & $\begin{array}{c}\text { Proportion of } \\
\left.\text { strong acid }^{\mathrm{sites}}{ }^{\mathrm{f}} \%\right)\end{array}$ \\
\hline KIT-6 & 812 & 1.34 & 7.0 & - & - & - \\
Ir/KIT-6-R500 & 721 & 1.18 & 6.6 & 52.0 & - & - \\
Ir-Re/KIT-6-R400 & 605 & 1.02 & 7.1 & 20.7 & 25 & 52 \\
Ir-Re/KIT-6-R500 & 623 & 1.05 & 7.0 & 21.6 & 44 & 54 \\
Ir-Re/KIT-6-R600 & 623 & 1.05 & 7.0 & 17.2 & 54 & 61 \\
Ir-Re/KIT-6-R700 & 636 & 1.04 & 6.8 & 18.8 & 50 & 67 \\
\hline
\end{tabular}

${ }^{a}$ Calculated using the BET method ( $\left.S_{\mathrm{BET}}\right)$.

b Pore volume $\left(V_{\mathrm{p}}\right)$, calculated using the BJH method.

${ }^{c}$ Pore size $\left(d_{\mathrm{p}}\right)$, calculated using the $\mathrm{BJ} \mathrm{H}$ method.

${ }^{\mathrm{d}}$ Dispersion (CO/Ir), estimated from $\mathrm{CO}$ chemisorption.

e Estimated from $\mathrm{NH}_{3}-\mathrm{TPD}$

fEstimated from deconvolution of $\mathrm{NH}_{3}$-TPD profiles.

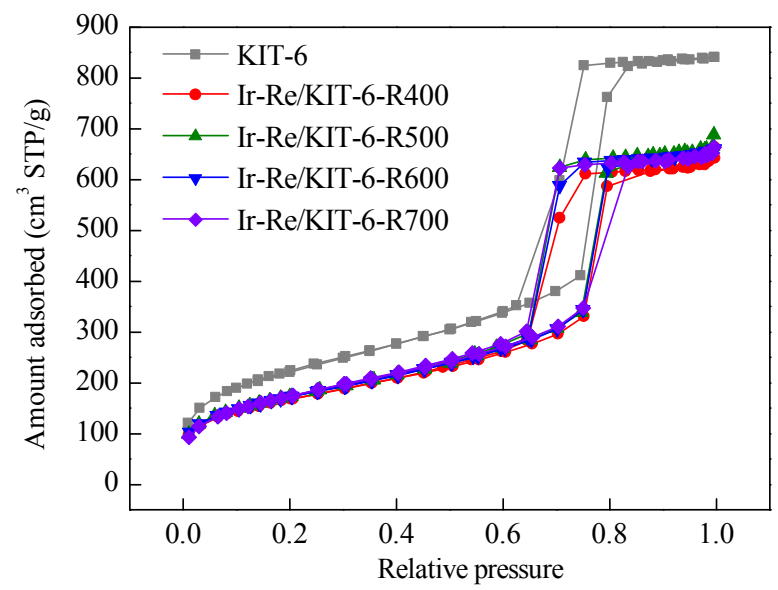

Fig. 1. $\mathrm{N}_{2}$ adsorption-desorption isotherms of KIT-6 and Ir-Re/KIT-6 catalysts reduced at different temperatures.

metal particles inside the mesoporous channels [18]. Nevertheless, these data show that changes in the reduction temperature have only a minimal effect on the textural properties of the catalysts. All catalysts exhibit mesoporous characteristics with a similar mean pore size of approximately $7 \mathrm{~nm}$.

Fig. 2 shows the TPR profiles of Ir/KIT-6, Re/KIT-6, and Ir-Re/KIT-6 without prior calcination treatments, as a means of

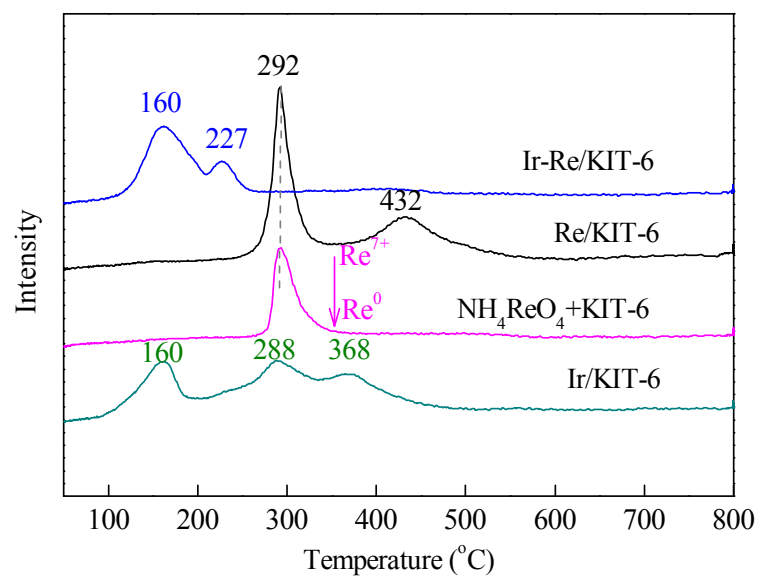

Fig. 2. TPR profiles of $\mathrm{Ir} / \mathrm{KIT}-6$, a physical mixture of $\mathrm{NH}_{4} \mathrm{ReO}_{4}$ and KIT-6, Re/KIT-6 and Ir-Re/KIT-6. 
assessing their reducibilities. Re/KIT-6 displays two hydrogen consumption peaks at 292 and $432{ }^{\circ} \mathrm{C}$. Because the position of the lower temperature peak is exactly the same as that observed for a physical mixture of $\mathrm{NH}_{4} \mathrm{ReO}_{4}$ and KIT-6, this peak can be assigned to the reduction of physisorbed $\mathrm{ReO}_{4}{ }^{-}$species. The hydrogen consumption peak appearing in the Re/KIT-6 data at $432{ }^{\circ} \mathrm{C}$ could be due to weakly chemisorbed $\mathrm{ReO}_{4}{ }^{-}$species on the oxide support, possibly through Re-oxygen interactions resulting from the high oxophilicity of Re [27]. The TPR profile of Ir/KIT-6 shows three main hydrogen consumption peaks, possibly owing to the reduction of different ionic iridium species $\left(\left[\mathrm{IrCl}_{6}\right]^{2-}\right.$, $\left[\mathrm{IrCl}_{5}\right]^{-}$and $\left.\mathrm{IrCl}_{4}\right)$ formed via ligand exchange [34], thus providing evidence for different types of iridium-support interactions [31].The presence of ionic iridium species is further demonstrated by the yellow appearance of the $\mathrm{Ir} / \mathrm{KIT}-6$ because $\mathrm{IrO}_{2}$ is black. These observations are in accordance with our previous report that the metal precursors are present in the form of ions on the hydrated support layer following impregnation and drying [18].

In the case of Ir-Re/KIT-6, two main hydrogen consumption peaks are observed at 160 and $227^{\circ} \mathrm{C}$. The peak at the higher temperature likely can be attributed to the reduction of chemisorbed Re species promoted by Ir. Compared with the Re/KIT- 6 data, the hydrogen consumption peaks generated by bimetallic Ir-Re/KIT-6 are obviously shifted to lower temperatures. This result indicates close contact between Ir and Re and shows that Ir can promote the reduction of Re species in bimetallic Ir-Re/KIT- 6 catalysts due to the hydrogen spillover effect. Furthermore, the metallic states were estimated based on the corresponding quantities of hydrogen consumption. It is evident that both Ir and Re species in monometallic catalysts can be reduced to metallic states. The formation of Re metal from $\mathrm{Re} / \mathrm{KIT}-6-\mathrm{R} 500$ and $\mathrm{NH}_{4} \mathrm{ReO}_{4}$ during TPR was further evidenced by XRD data (Fig. 3(a)). The full reduction of $\mathrm{NH}_{4} \mathrm{ReO}_{4}$ also indicates that the $\mathrm{ReO}_{4}{ }^{-}$species is reduced to the metallic state in one step rather than two [32]. In the case of Ir-Re/KIT-6, the hydrogen consumption amount equals that required to fully reduce both metal species. Based on these results, direct reduction of Ir-Re/KIT- 6 catalysts above $250{ }^{\circ} \mathrm{C}$ can fully reduce both metal species and thereby generate an
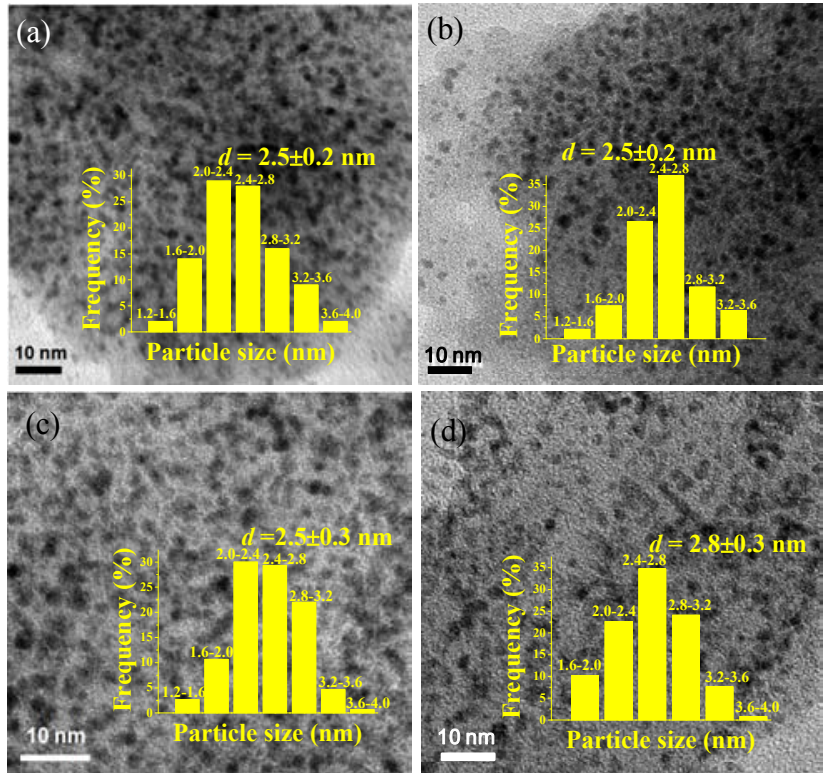

Fig. 4. TEM images and particle size distributions of Ir-Re/KIT-6 reduced at (a) 400, (b) 500, (c) 600, and (d) $700{ }^{\circ} \mathrm{C}$.

Ir-Re alloy.

Fig. 4 presents the TEM images and particle size distributions of Ir-Re/KIT- 6 catalysts. It should be noted here that the reduction temperature was raised from room temperature to each target temperature at a very slow ramp rate of $1^{\circ} \mathrm{C} / \mathrm{min}$ to inhibit the possible aggregation of metal particles. It can be seen that metal particles are well dispersed on the supports, with mean particle sizes of 2.5 to $2.8 \mathrm{~nm}$. Furthermore, all the Ir-Re/KIT-6 catalysts show very weak XRD peaks (Fig. 3b), similar to those previously reported for Ir-Re alloys $[18,25]$. Since the crystal size detection limit of XRD is ca. $3 \mathrm{~nm}$, this phenomenon could be ascribed to the high degree of metal dispersion and/or the possible presence of an amorphous phase $[25,26]$.

Fig. 5 shows the STEM-EDX elemental analysis data for randomly selected metal particles, and indicates the co-existence of both Ir and Re in a single metal particle. This
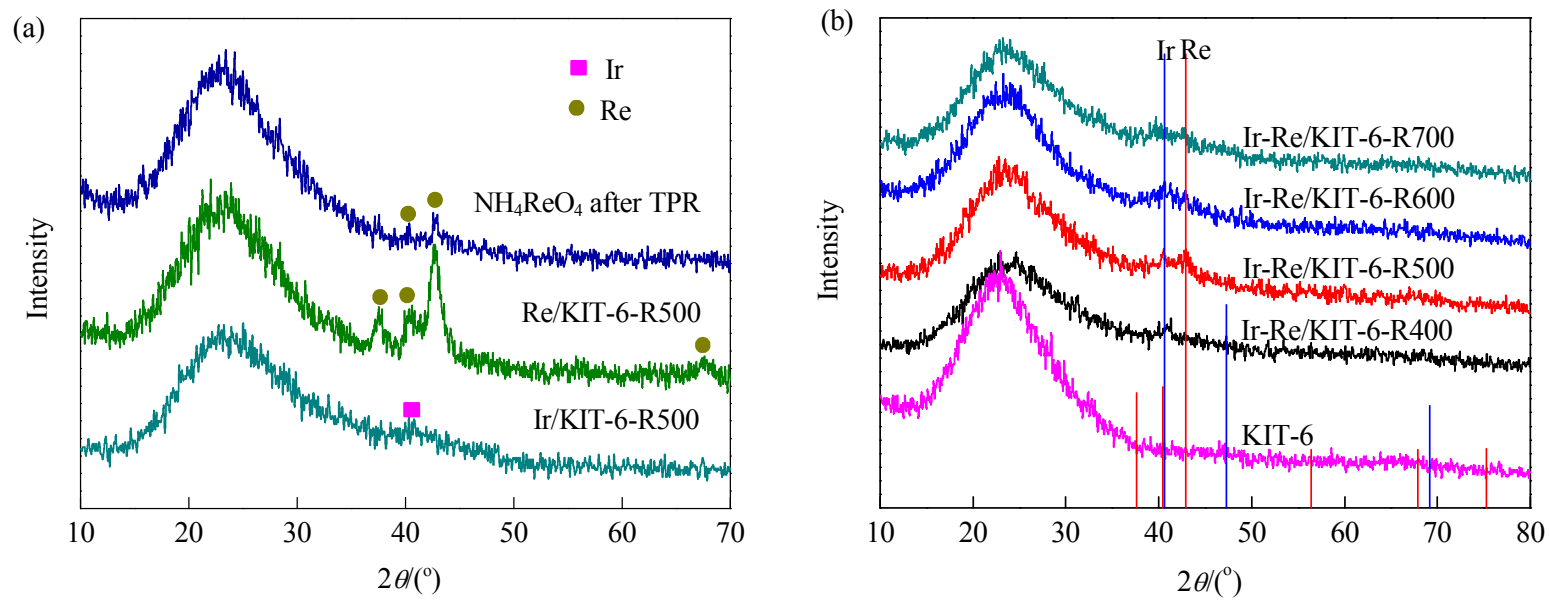

Fig. 3. XRD patterns of (a) monometallic catalysts and $\mathrm{NH}_{4} \mathrm{ReO}_{4}$ after TPR and (b) Ir-Re/KIT-6 reduced at various temperatures. 

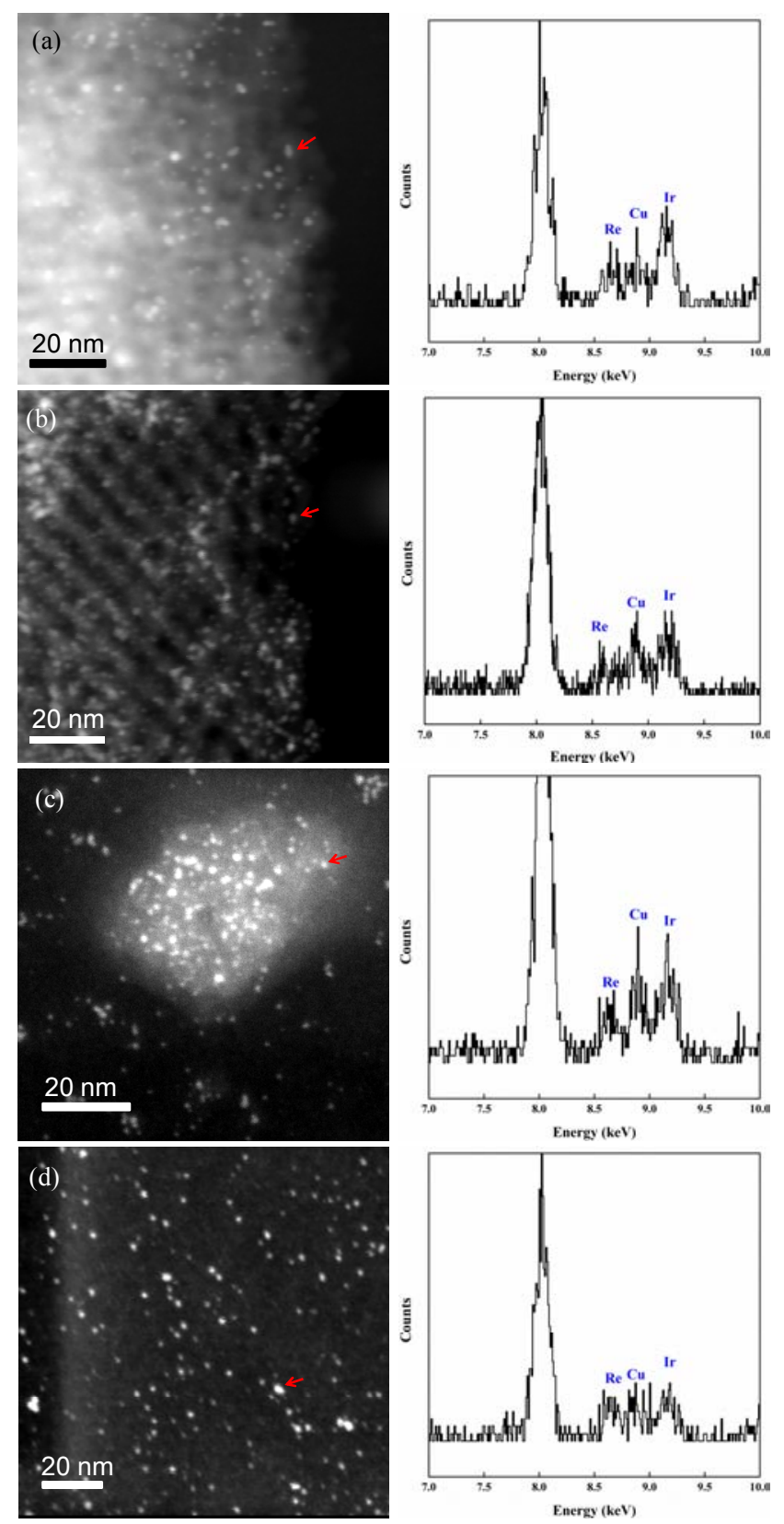

Fig. 5. HAADF-STEM images and spot EDX elemental analysis of randomly selected metal particles (marked by red arrows) of Ir-Re/KIT-6 reduced at (a) 400, (b) 500, (c) 600, and (d) $700{ }^{\circ} \mathrm{C}$.

result provides evidence for direct contact between Ir and Re. As suggested by $\mathrm{H}_{2}$-TPR results, the Ir and Re species undergo close interaction and can be completely reduced to metallic states. On this basis, it can be proposed that the Ir-Re alloy structure forms during reduction at $400-700^{\circ} \mathrm{C}$.

Fig. 6 summarizes the CO-DRIFT spectra of the Ir-Re/KIT- 6 catalysts. In a previous study [18], red-shifts of the CO band as well as changes in the band shape were proven to be effective and sensitive indicators of the formation of Ir-Re alloy on Ir-Re/KIT- 6 catalysts. As can be seen, all the Ir-Re/KIT-6 catalysts exhibit a similar CO adsorption band at approximately $2055 \mathrm{~cm}^{-1}$, a position that is exactly intermediate between the locations of 2068 and $2040 \mathrm{~cm}^{-1}$ that are assignable to Ir/KIT-6

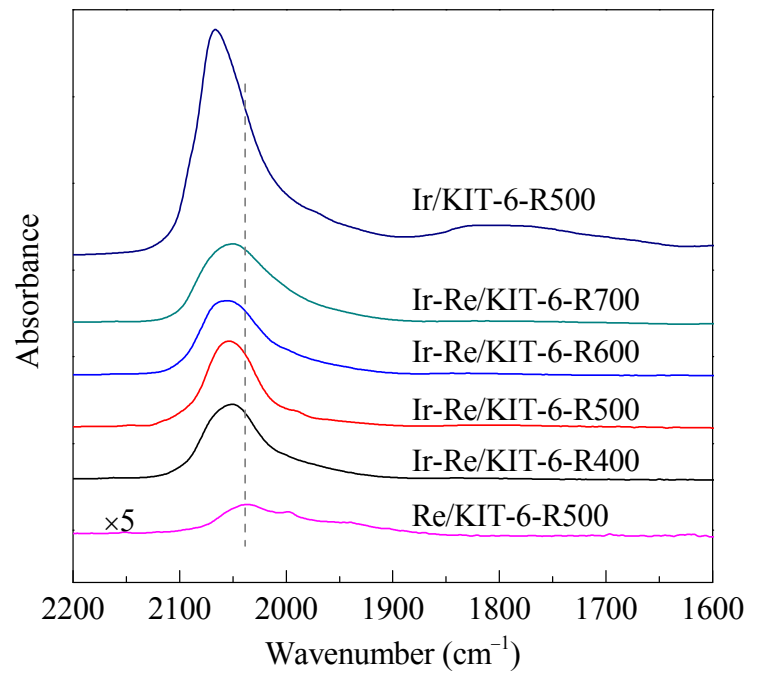

Fig. 6. CO-DRIFT spectra of Re/KIT-6 and Ir/KIT-6 pre-reduced at $500^{\circ} \mathrm{C}$ and $\mathrm{Ir}-\mathrm{Re} / \mathrm{KIT}-6$ reduced at various temperatures

and $\mathrm{Re} / \mathrm{KIT}-6$, respectively. Comparing the red-shift of the CO bands to the Ir/KIT-6 spectra suggests the increased back-donation of electrons from Ir to $\mathrm{CO}$ molecules as a result of the electron enrichment of Ir alloying with Re [29]. In addition, the bridged $\mathrm{CO}$ band at approximately $1800 \mathrm{~cm}^{-1}$ is absent for the Ir-Re/KIT-6 catalysts but is observed for the Ir/KIT-6, indicating that continuous surface Ir ensembles are separated by $\mathrm{Re}$ atoms. These results suggest that the Ir-Re/KIT-6 catalysts reduced at $400-700{ }^{\circ} \mathrm{C}$ are in the form of Ir-Re alloys.

Furthermore, it can be seen that the band intensities of these catalysts are very similar, implying that they possess similar CO adsorption capabilities. The Ir dispersions were further determined by $\mathrm{CO}$ chemisorption (Table 1). It should be noted that, as indicated by the CO-DRIFT spectra, the Re/KIT- 6 shows negligible CO chemisorption compared to the Ir/KIT-6. This is consistent with previous observations of Pt-Re catalysts [12]. As such, the Ir dispersion was considered to be correlated to the quantity of chemisorbed CO. In keeping with the CO-DRIFT results, all the Ir-Re/KIT-6 catalysts exhibit similar levels of Ir dispersion, and these levels are significantly lower than that of the Ir/KIT-6 with a similar particle size (i.e., 2.3 $\mathrm{nm})$. The lower CO chemisorption capability of Ir-Re/ KIT-6 compared with Ir/KIT- 6 can be explained by (i) the changes in the electronic properties of Ir resulting from alloying with Re and (ii) the dilution effect of the Re.

The acidity of bimetallic M (Pt, Rh, Ru, or Ir)-Re catalysts can be assessed by $\mathrm{NH}_{3}$-TPD $[12,17,23,27,36]$, and therefore this technique was employed to detect changes in the surface acidity of Ir-Re/KIT-6 catalysts with different reduction temperatures. As can be seen from Fig. 7, the $\mathrm{NH}_{3}$-TPD profiles of all Ir-Re/KIT-6 catalysts exhibit two peaks centered at approximately 185 and $260{ }^{\circ} \mathrm{C}$, indicating their similar acid strengths. It should be noted that the siliceous KIT-6 support typically shows negligible surface acidity [28]. The acidity in these materials likely originates from $\mathrm{Re}-\mathrm{OH}$ sites formed via the interaction between oxophilic Re and water molecules with the assis- 


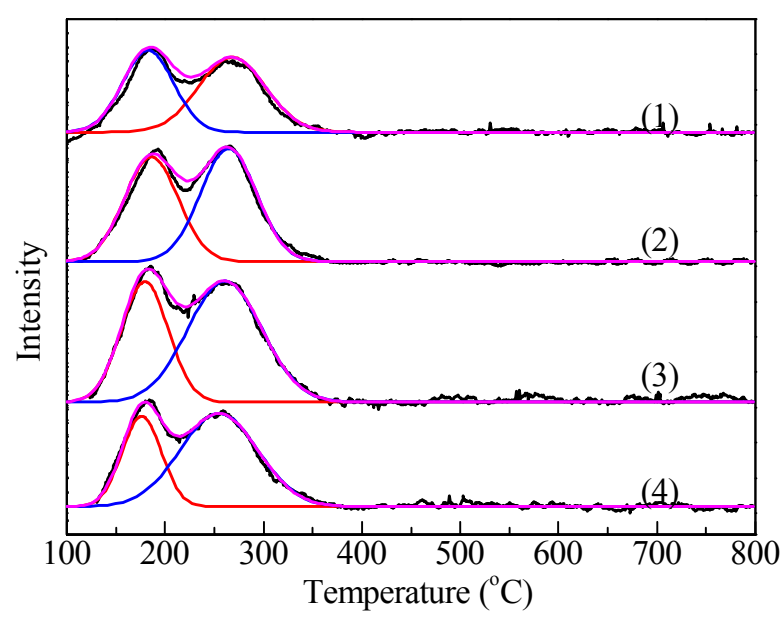

Fig. 7. $\mathrm{NH}_{3}$-TPD profiles of (1) Ir-Re/KIT-6-R400, (2) Ir-Re/KIT-6-R500, (3) Ir-Re/KIT-6-R600 and (4) Ir-Re/KIT-6-R700.

tance of reducible metals such as Pt, Rh and Ir [12,17,23,27]. The resulting Re-OH groups can act as Brönsted acid sites because of their ability to donate protons, due to the high oxophilicity of $\operatorname{Re}[23,27,35]$. Moreover, the Re-OH interacts strongly with the Ir (i.e., Ir-Re-OH), increasing the electron deficiency of the Re (as indicated by CO-DRIFTS), and hence generating higher acid strengths. Therefore, the observed different strengths of acid sites could be due to varying extents of Ir-Re interaction. In this regard, as reported previously, Re species interacting weakly with Ir produce weaker acid strengths as evidence by the $\mathrm{NH}_{3}$-desorption peak centered at $175^{\circ} \mathrm{C}$ in the case of the $\mathrm{Ir}-\mathrm{ReO}_{x}$ catalysts [18]. Furthermore, the deconvolution results show that increasing the reduction temperature leads to a higher percentage of strong acid sites (Table 1), possibly due to the stronger Ir-Re interaction at higher temperatures.

As shown in Table 1, the acid amount of Ir-Re/KIT-6 evidently increases with reduction temperature and reaches a maximum at $600{ }^{\circ} \mathrm{C}$. The opposite trend was observed in the case of a Rh-Re/C catalyst by Chia et al. [23], such that the surface acidity of $\mathrm{Rh}-\mathrm{Re} / \mathrm{C}$ decreased from 64 to $38 \mu \mathrm{mol} \cdot \mathrm{g}_{\mathrm{cat}^{-}}{ }^{-1}$ with increases in the reduction temperature from 250 to 450 ${ }^{\circ} \mathrm{C}$. These differing trends could be due to the different reduction temperatures employed and the nature of the metals. We propose that the higher number of acidic (Ir-) Re-OH sites in our work resulted from more uniform mixing of Ir and Re during reduction at high temperatures (Scheme 2), such that bimetallic Ir-Re/KIT-6 catalysts with more efficient Ir-Re interactions were obtained. Daniel et al. [13] has also reported that $\mathrm{Pt}-\mathrm{Re} / \mathrm{C}$ reduced at $700{ }^{\circ} \mathrm{C}$ shows better atomic mixing of $\mathrm{Pt}$ and $\mathrm{Re}$ than when reduced at $450{ }^{\circ} \mathrm{C}$. In addition, the slight decrease in the acid amount in the case of the catalyst reduced at $700{ }^{\circ} \mathrm{C}$ could be the result of its larger particle size (2.8 vs. $2.5 \mathrm{~nm})$.

\subsection{Acidity-reactivity relationship}

Glycerol hydrogenolysis trials with Ir-Re/KIT-6 catalysts reduced at various temperatures were conducted using conditions consisting of $8 \mathrm{MPa} \mathrm{H}_{2}, 120{ }^{\circ} \mathrm{C}$ and $20 \mathrm{~g}$ of an aqueous glycerol solution (20 wt\%), with the results summarized in Table 2. It is evident that the activity (expressed as a specific rate) increases with the reduction temperature from 400 to $600{ }^{\circ} \mathrm{C}$ and then remains almost unchanged when increasing the temperature to $700{ }^{\circ} \mathrm{C}$. A bifunctional mechanism for glyc-

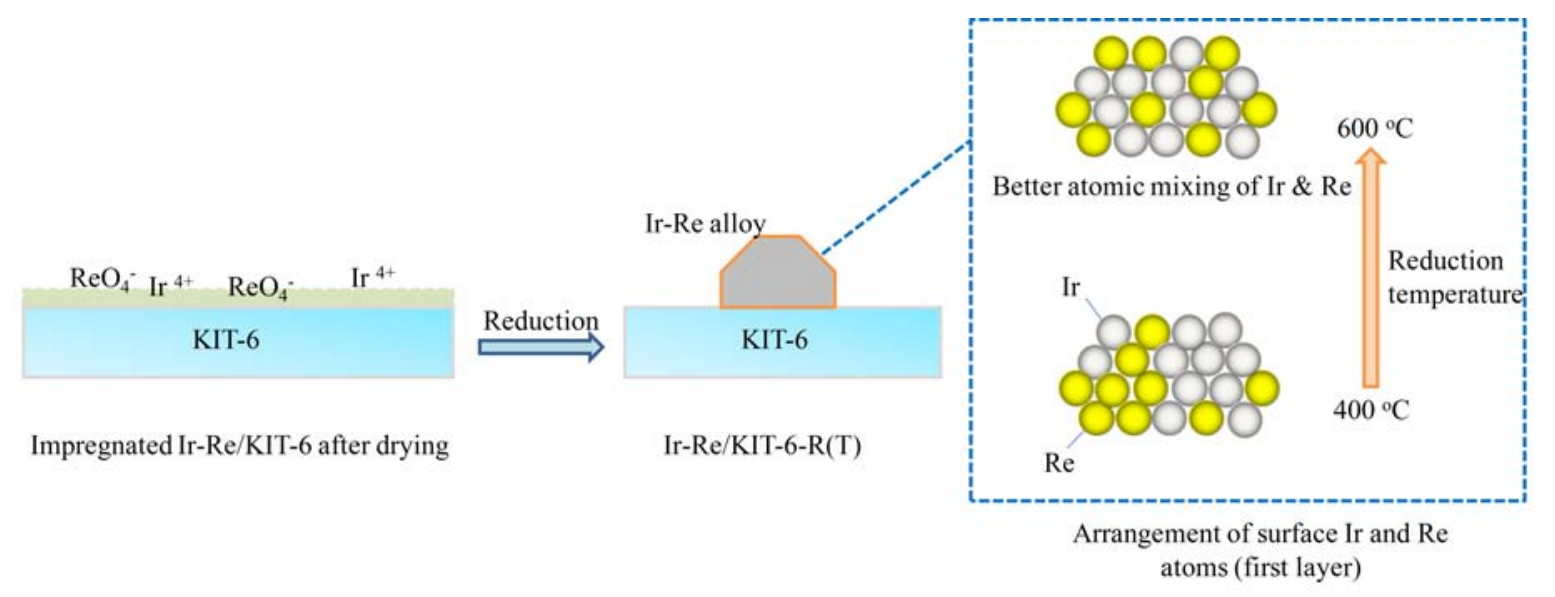

Scheme 2. Possible effect of reduction temperature on bimetallic Ir-Re catalysts.

Table 2

Effect of reduction temperature on the catalytic performance of uncalcined Ir-Re/KIT-6 catalysts for glycerol hydrogenolysis.

\begin{tabular}{|c|c|c|c|c|c|c|}
\hline \multirow{2}{*}{ Sample } & \multirow{2}{*}{$\begin{array}{c}\text { Conversion } \\
(\%)\end{array}$} & \multirow{2}{*}{$\begin{array}{c}\text { Specific rate } \\
\left(\mathrm{mol} \cdot \mathrm{mol}_{\mathrm{Ir}}{ }^{-1} \cdot \mathrm{h}^{-1}\right)\end{array}$} & \multicolumn{4}{|c|}{ Selectivity (\%) } \\
\hline & & & 1,3-PD & 1,2-PD & 1-PO & 2-PO \\
\hline$\overline{\mathrm{Ir}-\mathrm{Re} / \mathrm{KIT}-6-\mathrm{R} 400}$ & 26.3 & 30.7 & 39.0 & 24.5 & 28.5 & 8.0 \\
\hline Ir-Re/KIT-6-R500 & 39.7 & 46.4 & 37.1 & 25.8 & 28.0 & 9.1 \\
\hline Ir-Re/KIT-6-R600 & 46.3 & 54.1 & 33.0 & 22.2 & 33.3 & 11.5 \\
\hline Ir-Re/KIT-6-R700 & 44.5 & 52.0 & 31.7 & 25.0 & 35.1 & 8.2 \\
\hline
\end{tabular}

Reaction conditions: $120^{\circ} \mathrm{C}, 8 \mathrm{MPa}, 12 \mathrm{~h}$, catalyst $150 \mathrm{mg}, 20 \mathrm{wt} \%$ glycerol aqueous solution $20 \mathrm{~g}$. 
erol hydrogenolysis has been proposed for bimetallic $\mathrm{M}(\mathrm{Pt}, \mathrm{Rh}$, Ir)-Re catalysts that possess both metallic $M$ sites and acidic (M-)Re-OH sites $[12,17,23,27]$. It has been suggested that the acidic (Ir-)Re-OH sites and the metallic Ir sites are responsible for glycerol adsorption and hydrogen activation during the hydrogenolysis reaction, respectively $[10,18]$. Therefore, the catalytic performance of Ir-Re/KIT-6 during glycerol hydrogenolysis is related to both the Ir dispersion and the acidic properties of the material.

As noted, the reduction temperature has a negligible effect on the number of surface Ir sites. In addition, the acid strength is not obviously changed by the reduction temperature. Having excluded the effects of Ir dispersion and acid strength on the catalytic performance, the acid amount can be directly correlated with the reactivity (expressed as a specific rate), as shown in Fig. 8. The activity is observed to increase linearly with the acid amount. This linear relationship strongly indicates the direct influence of surface acidity on activity, and provides experimental evidence for the bifunctional mechanism of Ir-Re alloy catalysts.

Because the reaction order with respect to glycerol over Ir-Re/KIT-6 is zero [18], the adsorption of glycerol on acidic (Ir-)Re-OH sites must be rather strong [17-18]. This means that the acidic (Ir-) Re-OH sites are involved in the rate-determining step and that acid density plays a vital role in determining the activity of Ir-Re catalysts. These findings provide fundamental knowledge concerning the role of Re in the Ir-Re alloy and suggest measures that could be taken to improve the performance of Ir-Re catalysts, such as increasing the Re content or enhancing the Ir-Re alloying extent.

The hydrogenolysis of glycerol over bimetallic Ir-Re catalysts generates the primary hydrogenolysis products 1,3-PD and 1,2-PD and the secondary hydrogenolysis products 1-PO and 2-PO [10]. As shown in Table 1, with increasing glycerol conversion, the selectivity for 1,3-PD decreases with a concomitantly increased selectivity for 1-P0. However, the selectivity for 1,2-PD does not undergo a significant decrease. The difference in the behaviors of 1,3-PD and 1,2-PD implies changes in the microstructures of the Ir-Re catalysts that might be related

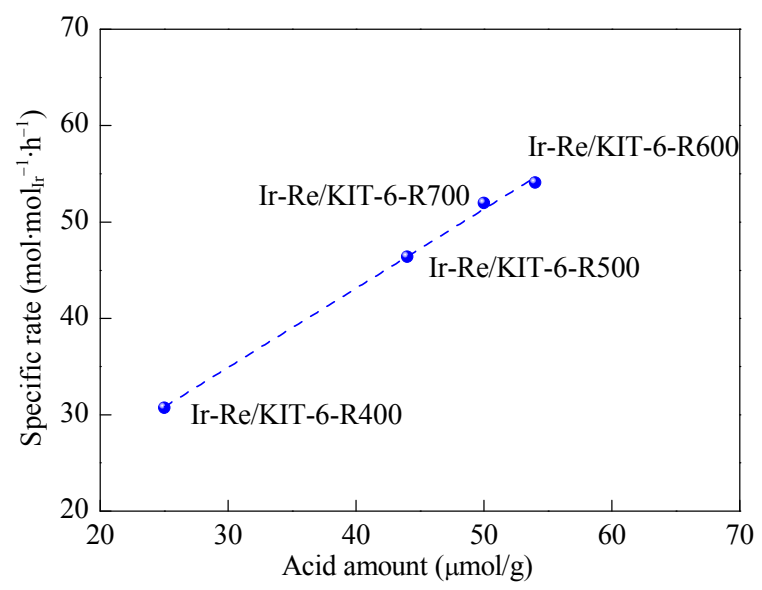

Fig. 8. Correlation between acid amount and activity in glycerol hydrogenolysis (expressed as specific rate). to the synergy between Ir and Re-OH groups and their changing acid strengths. The effect of acidity on product distribution therefore requires further investigation.

\section{Conclusions}

In this work, we investigated the effects of reduction temperature on the properties of bimetallic Ir-Re/KIT- 6 catalysts prepared by a direct reduction method. The results showed that the bimetallic Ir-Re structures of catalysts reduced at 400-700 ${ }^{\circ} \mathrm{C}$ are in the form of Ir-Re alloys that exhibit similar mean particle sizes, Ir dispersions and acid strengths but varied acid densities. It has been found that increasing the reduction temperature from 400 to $600{ }^{\circ} \mathrm{C}$ leads to a higher number of surface acid sites on the Ir-Re/KIT- 6 catalyst due to the more efficient Ir-Re interaction, resulting in increased activity during glycerol hydrogenolysis and decreased selectivity for 1,3-propanediol. However, the activity of an Ir-Re/KIT-6 catalyst reduced at $700{ }^{\circ} \mathrm{C}$ was observed to slightly decrease, likely as a result of the growth of the metal particles. Furthermore, a linear relationship between activity during glycerol hydrogenolysis and acidic (Ir-)Re-OH density was established. This fact strongly suggests the vital role of acidity in glycerol hydrogenolysis over Ir-Re alloys. The present study provides fundamental knowledge that should assist in optimizing bimetallic Ir-Re catalysts and designing novel bimetallic catalysts for glycerol hydrogenolysis.

\section{References}

[1] Corma A, Iborra S, Velty A. Chem Rev, 2007, 107: 2411

[2] Huber G W, Iborra S, Corma A. Chem Rev, 2006, 106: 4044

[3] Nakagawa Y, Tomishige K. Catal Sci Technol, 2011, 1: 179

[4] Pagliaro M, Ciriminna R, Kimura H, Rossi M, Della Pina C. Angew Chem Int Ed, 2007, 46: 4434

[5] Chai S H, Wang H P, Liang Y, Xu B Q. Green Chem, 2007, 9: 1130

[6] Jia C J, Liu Y, Schmidt W, Lu A H, Schüth F. J Catal, 2010, 269: 71

[7] Omata K, Izumi S, Murayama T, Ueda W. Catal Today, 2013, 201: 7

[8] Wang Z, Wang L, Jiang Y, Hunger M, Huang J. ACS Catal, 2014, 4: 1144

[9] Zhang Y, Zhao X C, Wang Y, Zhou L K, Zhang J Y, Wang J, Wang A Q, Zhang T.J Mater Chem A, 2013, 1: 3724

[10] Nakagawa Y, Shinmi Y, Koso S, Tomishige K. J Catal, 2010, 272: 191

[11] Zhu S H, Gao X Q Zhu Y L, Zhu Y F, Xiang X M, Hu C X, Li Y W. Appl Catal B, 2013, 140: 60

[12] Deng C H, Duan X Z, Zhou J H, Chen D, Zhou X G, Yuan W K. Catal Today, 2014, 234: 208

[13] Daniel O M, Delariva A, Kunkes E L, Datye A K, Dumesic J A, Davis R J. ChemCatChem, 2010, 2: 1107

[14] Ma L, He D H. Catal Today, 2010, 149: 148

[15] Qin L Z, Song M J, Chen C L. Green Chem, 2010, 12: 1466

[16] Arundhathi R, Mizugaki T, Mitsudome T, Jitsukawa K, Kaneda K. ChemSusChem, 2013, 6: 1345

[17] Nakagawa Y, Ning X, Amada Y, Tomishige K. Appl Catal A, 2012, 433-434: 128

[18] Deng C H, Duan X Z, Zhou J H, Zhou X G, Yuan W K, Scott S L. Catal Sci Technol, 2015, 5: 1540

[19] Vasiliadou E S, Eggenhuisen T M, Munnik P, de Jongh P E, de Jong 


\title{
Graphical Abstract
}

Chin. J. Catal., 2015, 36: 1750-1758 doi: 10.1016/S1872-2067(15)60899-3

\section{Effects of pretreatment temperature on bimetallic Ir-Re catalysts for glycerol hydrogenolysis}

Chenghao Deng, Li Leng, Jinghong Zhou*, Xinggui Zhou, Weikang Yuan East China University of Science and Technology

A linear correlation between the surface acid quantity of Ir-Re alloys and catalytic activity during glycerol hydrogenolysis was established, and it was found to be possible to modify the acid amount by varying the reduction temperature.

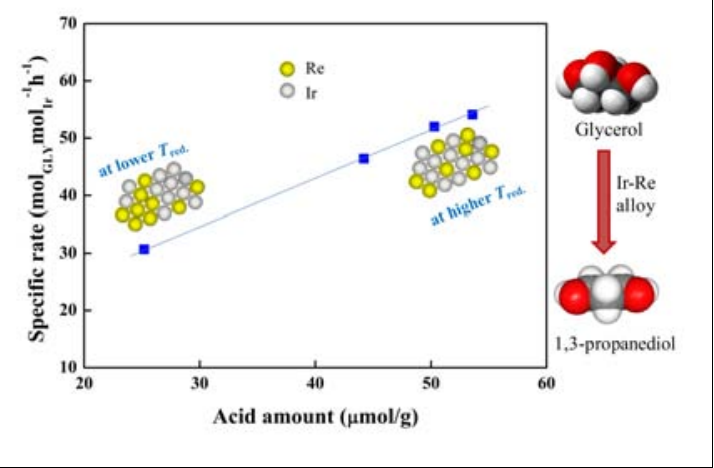

K P, Lemonidou A A. Appl Catal B, 2014, 145: 108

[20] Wu Q, Eriksen W L, Duchstein L D L, Christensen J M, Damsgaard C D, Wagner J B, Temel B, Grunwaldt J, Jensen A D. Catal Sci Technol, 2014, 4: 378

[21] Rønning M, Gjervan T, Prestvik R, Nicholson D G, Holmen A. J Catal, 2001, 204: 292

[22] Prestvik R, Moljord K, Grande K, Holmen A. J Catal, 1998, 174: 119

[23] Chia M, O'Neill B J, Alamillo R, Dietrich P J, Ribeiro F H, Miller J T, Dumesic J A. J Catal, 2013, 308: 226

[24] Epron F, Gauthard F, Barbier J. Appl Catal A, 2002, 237: 253

[25] Karan H I, Sasaki K, Kuttiyiel K, Farberow C A, Mavrikakis M, Adzic R R. ACS Catal, 2012, 2: 817

[26] Hirasawa S, Watanabe H, Kizuka T, Nakagawa Y, Tomishige K. J Catal, 2013, 300: 205

[27] Chia M, Pagan-Torres Y J, Hibbitts D, Tan Q, Pham H N, Datye A K, Neurock M, Davis R J, Dumesic J A. J Am Chem Soc, 2011, 133:
12675

[28] Karthikeyan G, Pandurangan A.J Mol Catal A, 2012, 361-362: 58

[29] Haneda M, Kudo H, Nagao Y, Fujitani T, Hamada H. Catal Commun, 2006, 7: 423

[30] Kleitz F, Choi S H, Ryoo R. Chem Commun, 2003: 2136

[31] Borda G, Rojas H, Murcia J, Fierro J L G, Reyes P, Oportus M. React Kinet Catal Lett, 2007, 92: 369

[32] Simonetti D A, Kunkes E L, Dumesic J A.J Catal, 2007, 247: 298

[33] Guan J, Chen X F, Peng G M, Wang X C, Cao Q, Lan Z G, Mu X D. Chin $J$ Catal (关静, 陈秀芳, 彭功名, 王喜成, 曹泉, 兰峥岗, 牟新东. 催 化学报), 2013, 34: 1656

[34] Amrousse R, Hori K, Fetimi W. Catal Commun, 2012, 27: 174

[35] Zhang L, Karim A M, Engelhard M H, Wei Z, King D L, Wang Y. J Catal, 2012, 287: 37

[36] Ma L, Li Y M, He D H. Chin J Catal (马兰, 李宇明, 贺德华. 催化学 报), 2011, 32: 872

\section{预处理温度对甘油氢解双金属Ir-Re催化剂性能的影响}

\author{
邓澄浩, 冷 莉, 周静红*, 周兴贵, 袁渭康 \\ 华东理工大学化工学院, 上海200237
}

摘要: 在生物柴油生产过程中大量副产的甘油是重要的生物质转化平台化合物. 通过甘油氢解制备高附加值的1,3-丙二醇是甘油 的资源化利用的重要途径, 能够显著提高生物柴油产业的经济效益, 同时也是探究更复杂的糖醇类化合物氢解的模型反应. 因此, 甘油氢解制备1,3-丙二醇成为当前学术界的研究热点. 通常, 以Re或W为助剂修饰的贵金属催化剂是有效的甘油选择性氢解制 1,3-丙二醇的催化剂, 其中, 双金属Ir-Re催化剂是目前最高效的催化剂之一. 甘油氢解反应是典型的结构敏感性反应, 它的催化性 能依赖于双金属催化剂的结构, 而后者受制备工艺条件如热处理方式及条件的影响. 最近, 我们报道了以直接还原法(即浸渍-还 原法)制备的Ir-Re催化剂为合金结构, 在甘油氢解中表现出更为优越的反应活性及目前报道中最高的 1,3-丙二醇生成速率, 并提出 了可能的双功能反应机理, 即催化剂表面的Re-OH酸性位和Ir均为甘油氢解的活性位. 本文采用直接还原法制备KIT-6 (具有三维 有序介孔孔道结构的 $\mathrm{SiO}_{2}$ ) 负载的双金属Ir-Re催化剂, 进一步研究还原温度对Ir-Re/KIT-6的结构及其催化性能的影响, 揭示催化 剂表面酸性在甘油氢解反应中的重要作用并阐明其构-效关系.

结果显示不同还原温度 $\left(400-700{ }^{\circ} \mathrm{C}\right)$ 制备的催化剂的比表面积、孔体积及孔径数据基本一致, 表明还原温度对Ir-Re/KIT-6的 织构性质的影响很小. 根据程序升温还原和透射电镜-能量散射点扫描结果可知, 不同温度还原后的催化剂表面Ir和Re均以金属 态形式存在, 同时两者存在直接的相互作用, 形成了Ir-Re合金; 而漫反射红外图谱上CO吸附峰的红移以及峰形的显著变化也印 证了 Ir-Re合金结构的形成. TEM结果显示, 在 400-700 ${ }^{\circ} \mathrm{C}$ 还原后得到的 Ir-Re合金纳米粒子均匀分布于KIT- 6 上, 尺寸基本一致 $(2.5-2.8 \mathrm{~nm})$, 与 $\mathrm{CO}$ 化学吸附结果一致. 此外, $\mathrm{NH}_{3}$-程序升温脱附结果表明催化剂的酸量随着还原温度的升高而逐渐增大, 但酸强 度没有明显变化, 这可能是由于高温还原进一步促进了 Ir和Re的相互作用, 在原子尺度上混合更为均匀所致. Ir-Re催化剂上甘油 氢解反应结果显示, 随着还原温度由 400 提高到 $600{ }^{\circ} \mathrm{C}$, 所制催化剂的活性先增加而后趋于稳定. 由此可以认为 Ir-Re催化性能的差 
异与Ir分散度和酸强度的关联较小, 主要是由于催化剂表面酸量所致. 直接关联酸量与反应活性(以反应时间内的平均 1,3 -丙二醇 生成速率表示)可以看到, 反应活性随着酸量的增加而线性增大, 表明Ir-Re/KIT-6的表面酸量直接影响了甘油氢解反应速率的快 慢, 即酸位 $\mathrm{Re}-\mathrm{OH}$ 直接参与了催化反应. 众所周知, $\mathrm{Re}$ 金属活化 $\mathrm{H}_{2}$ 的能力很弱, 而金属Ir在反应中起到催化加氢的作用. 实验结果 很好地印证了Ir-Re合金催化甘油氢解反应的双功能反应机理, 即酸位Re-OH与金属Ir协同参与氢解反应, 分别作为甘油吸附位和 $\mathrm{H}_{2}$ 活化中心, 因此提高催化剂的表面Re-OH的数量将是进一步提高催化活性的途径之一.

总的来说, 在 $400-700{ }^{\circ} \mathrm{C}$ 还原得到的Ir-Re/KIT-6催化剂具有Ir-Re合金结构. 还原温度对催化剂的织构性质、金属纳米粒子的 尺寸、Ir的分散度及表面酸强度的影响不大, 但还原温度的升高有利于Ir和Re的相互作用, 显著提高了催化剂的表面酸量, 因而提 高催化活性. 此外, 表面酸量和反应活性的线性关系表明酸位Re-OH参与Ir-Re合金催化甘油氢解反应, 印证了双功能反应机理. 关键词: 甘油氢解；铱-锞合金; 双功能反应机理；表面酸性；还原温度

收稿日期: 2015-03-11. 接受日期：2015-05-16. 出版日期: 2015-10-20.

*通讯联系人. 电话: (021)64252169; 传真: (021)64253528; 电子信箱: jhzhou@ecust.edu.cn

基金来源：国家自然科学基金(21106047).

本文的英文电子版由Elsevier出版社在ScienceDirect上出版(http://www.sciencedirect.com/science/journal/18722067). 